DOI: https://doi.org/10.24144/2409-6857.2018.2(52).115-118

УДК 658.3

Дюк О.М.

\title{
ТЕОРЕТИКО-МЕТОДИЧНІ ОСНОВИ ОЦІНКИ СТАНУ КОРПОРАТИВНОЇ КУЛЬТУРИ
}

\begin{abstract}
Проведено аналіз основних методів оцінки стану корпоративної культури на підприємстві. Аналіз показав, шчо на сьогоднішній день не існує єдиного підходу до очінки стану корпоративної культури на підприємстві. Було запропоновано власний підхід, який включає систему показників, які розподілені на декілька складових: соціально-економічна сфера, інтелектуально-інноваційна сфера; внутрішньополітична сфера; сфера особистості. Такий розподіл дозволить максимально чітко встановити реальний стан корпоративної культури на підприємстві.
\end{abstract}

Ключові слова: корпоративна культура, підприємтво, очінка стану корпоративної культури.

Постановка проблеми. Сьогодні корпоративна культура не є новим поняттям і для значної кількості провідних підприємств вона займає одне 3 ключових місць в переліку інструментів, які допомагають забезпечити його сталий розвиток. Через це, для вітчизняних підприємств, які прагнуть вийти на європейський рівень, проблематика корпоративної культури набуває ще більшої актуальності. На жаль, для переважної кількості вітчизняних підприємств роль корпоративної культури залишається на другому плані, що також привносить негативний наслідок і стимулює розвиток кризової ситуації. Останні події в нашій країні характеризуються економічною і політичною нестабільністю, що лише підсилює знищення корпоративних цінностей підприємств, тому слід переглянути $\mathrm{i}$ переосмислити саму концепцію і діючі моделі корпоративної культури, що не можливо без результатів оцінки іï поточного стану на підприємстві.

Аналіз останніх досліджень і публікацій. 3 часів незалежності України значна кількість науковців досліджувала поняття корпоративної культури, серед них можна виділити наукові праці О.Амоші, Т. Беляк, Г. Захарчиної, О. Єськової, М. Овчаренко, Г. Назарова та ін. Також слід відзначити наукові здобутки у розвитку корпоративної культури зарубіжних вчених: М. Армстронг, Р. Акофф, К. Голд, А. Кеннеді, Р. Куін, Т. Питерс та ін. Але враховуючи значні наукові напрацювання зі сторони як вітчизняних так i зарубіжних науковців, на сьогоднішній день $\epsilon$ потреба у формуванні теоретико-методичних основ оцінки стану корпоративної культури на підприємстві 3

\footnotetext{
(C) Дюк Оксана Михайлівна, здобувач, ІваноФранківський національний технічний університет нафти і газу, м. Івано-Франківськ, тел.:+380663962642, email: drvel@ukr.net
}

врахування сучасних умов розвитку.

Формулювання цілей статті. Мета статті полягає в дослідженні основних методів оцінки стану корпоративної культури.

Опис основного матеріалу дослідження. Поняття «корпоративна культура» пройшло складний історичний шлях. Впродовж тривалого періоду часу іiі тлумачення, основні цілі, принципи постійно змінювались. До прикладу, на етапі виникнення у XIX ст., термін «корпоративна культура» охоплював лише атрибутику в одязі та спілкуванні військових [1, c.120], коли вже у XX ст. поняття суттєво розширили i почали застосовувати до підприємств і організацій [2-3].

Підходи науковців до тлумачення поняття «корпоративна культура» суттєво відрізняються, Елдрідж Д. і Кромбі А. [4] відмічають, що корпоративна культура - це унікальні характеристики особливостей організації. Мескон М., М. Альберт та Хедоури Ф. [5] вважають, що корпоративна культура - це свого роду клімат в організації, який відображає його звичаї.

Цікавою є думка Хофстеда Г. [6,c.12], який вважає, що корпоративну культуру слід розглядати як колективне програмування думок, яке дозволяє виділити членів організації від інших.

На нашу думку, корпоративну культуру слід розглядати як систему унікальних якостей $\mathrm{i}$ особливостей підприємства, які дозволяють йому вирізняться серед інших та досягнути бажаного економічного ефекту.

Не лише трактування поняття «корпоративна культура» має значну кількість варіацій, але і іiі оцінка на підприємстві. Оскільки корпоративна культура не відображається в фінансовій звітності, а лише може допомогти в її покращені, iіi оцінка має багато складностей. 
При проведенні оцінки стану корпоративної культури на підприємстві, необхідно розуміти, що вона має значний вплив не лише на соціальну складову підприємства, але й на технологічну, економічну, інноваційну i організаційну, i 3 часом накопичилась значна кількість підходів до оцінки стану корпоративної культури на підприємстві. За результатами дослідження наукової літератури [7-8], ми виділили основні підходи до оцінювання стану корпоративної культури на підприємстві:

1. Еталонний метод оцінки стану корпоративної культури на підприємстві. Передбачає визначення спроможності показників об'єкта дослідження досягнути еталонний ступінь. Його головним недоліком $є$ те, що дуже складно встановити той самий стандартизований еталон.

2. Метод експертних оцінок. Являє собою залучення групи експертів, які дають оцінку рівня корпоративної культури на підприємстві. Даний метод страждає через те, що несе виключно суб'єктивний характер i вимагає значних витрат на залучення компетентних експертів.

3. Система абсолютних та відносних показників. Передбачає аналіз на основі реальних даних підприємства, і тому не завжди можна охопити усю діяльність підприємства.

4. Графічний метод оцінки рівня корпоративної культури. Даний метод дозволяє наочно продемонструвати оцінку корпоративної культури, але потребує значної кількості точних статистичних даних від підприємства.

5. Проведення регресійного аналізу. Дозволяє відобразити часові ряди показників, але, на жаль, даний аналіз не дозволяє здійснити будь-яку прогнозну оцінку показників.

6. Кластерний аналіз. Даний метод передбачає поділ усіх об’єктів на декілька кластерів, так щоб складові одного кластера були подібні між собою. При цьому, для кластерного аналізу не характерний суб'єктивізм отриманих даних.

Кожний $з$ представлених методів оцінки стану корпоративної культури на підприємстві має як свої переваги, так і недоліки через що який би 3 методів керівництво підприємства не обрало, не буде можливості в повному обсязі оцінити поточний стан корпоративної культури.

Як вже було сказано раніше, корпоративна культура являє собою відокремлену систему підприємства і тісно пов'язана в ті чи ініші мірі, 3 іiі іншими складовими. Тому проведення оцінки стану корпоративної культури на підприємстві повинно базуватись на показниках, які охоплють інші складові підприємства.

На сьогоднішній день не існує комплексного підходу до оцінки корпоративної культури на підприємстві, який би включав ті показники, що дозволяють врахувати різні сфери внутрішнього середовища підприємства, які формують його культуру. 3 цією метою, ми, за результатами оцінки існуючих методів оцінки стану корпоративної культури та аналізу наукової літератури [8-11], сформували комплексний підхід, який включає систему показників для проведення оцінки стану корпоративної культури на вітчизняному підприємстві 3 врахування сучасних умов розвитку (рис.1).

Як видно 3 рис.1, загальна оцінка стану корпоративної культури підприємства залежить від розрахунку ряду показників 3 наступних складових: соціально-економічна сфера; інтелектуально-інноваційна сфера; внутрішньополітична сфера; сфера особистості .

Соціально-економічна сфера оцінки корпоративної культури підприємства передбачає показники, які найкраще розкривають організацію і умови праці. Окрім цього слід пам'ятати і про економічні показники, які дозволять побачити результати роботи працівників підприємства.

Інтелектуально-інноваційна сфера полягає в аналізі професіоналізму в середині підприємства і визначенні рівня креативності серед персоналу.

Внутрішньополітична сфера включає показників, які характеризують ставлення персоналу підприємства до його внутрішньої політики.

Сфера особистості направлена на дослідження індивідуальних якостей працівників i їх прагнення постійно розвиватись.

Кожна із запропонованих сфер має ряд показників, які так чи інакше впливають на загальну оцінку корпоративної культури підприємства і тому, в подальшому для кожного необхідно встановити відповідну питому вагу значуваності для проведення оцінки. Кожне підприємство може використати ряд сучасних методів, які дозволять зібрати необхідну інформацію для проведення оцінки: проведення анкетування, спостереження, використання статистичних даних, тощо.

Висновки i перспективи подалыших досліджень. Нами було розглянуто основні методи оцінки стану корпоративної культури на підприємстві і за результатами дослідження, сформовано комплексний підхід до оцінки стану корпоративної культури 3 врахуванням основ- 


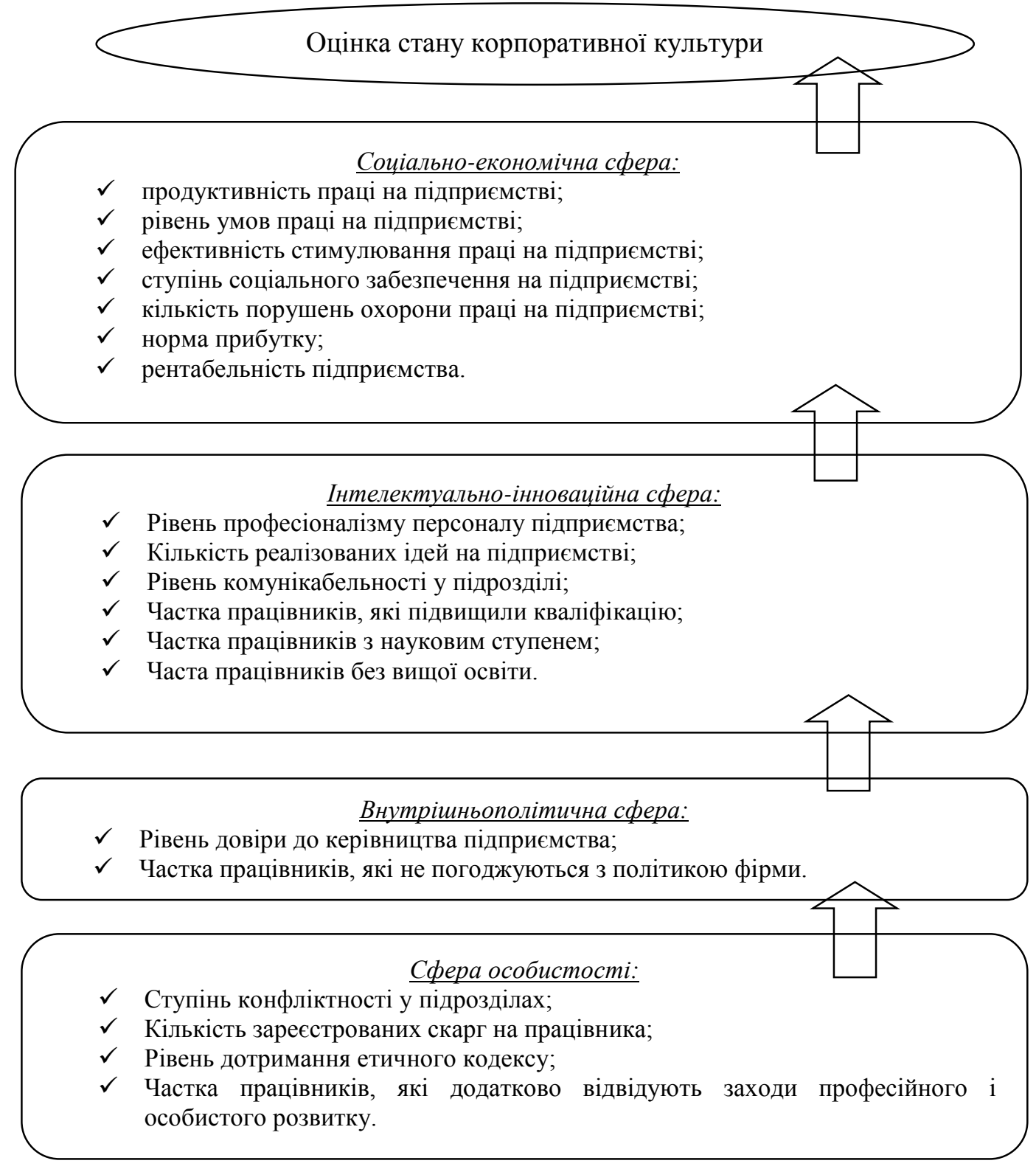

\section{Рис.1. Комплексний підхід до формування системи показників для проведення оцінки стану корпоративної культури на підприємстві*}

*Сформовано автором

них трьох сфер внутрішнього середовища підприємства, які в найбільшій мірі розкривають поточний стан корпоративної культури. В подальшому, необхідно застосувати запропо- нований підхід на практиці та визначити місце корпоративної культури у процесі вибору найефективніших технологій управління на вітчизняних підприємствах.

\section{ПЕРЕЛІК ВИКОРИСТАНИХ ДЖЕРЕЛ}

1. Арнаутова Ю.Е. Средневековые истоки современной корпоративной культуры / Ю.Е. Арнаутова // Менеджмент в России и за рубежом. 2008. - № 1. - С. $119-123$.

2. Управление человеческими ресурсами / Под ред. М. Пула, М. Уорнера. - СПб. : Питер, 2002. - 1200 с.

3. Fey C.F., Denison D.R. Organizational Culture and Effectiveness: the Case of Foreign Firms of Russia. Working Paper Number 179. December 1998. - [Электронный pecypc]. — Режим доступу : http:// www.econpapers.org.

4. Fayol Henri. Administration Industrielle et Générale, 1916. Анри Файоль. Общее и промышленное управление. - М. : 1923. - [Электронный ресурс]. — Режим доступа : http://gtmarket.ru/laboratory/basis/5783 
5. Hofstede Geert Culture's Consequencer: International Differences in Work Related Volues [Text]. London: Sage Publications, 1980. - $55 \mathrm{p}$.

6. Мескон М. Альберт М., Хедоури Ф.. Основы менеджмента / М. Мескон, М. Альберт, Ф. Хедоури. Москва : Издательство "Дело", 1997. — 704 с.

7. Беляк Т.О. Активізація впливу корпоративної культури на розвиток соціально-трудових відносин / Т.О. Беляк // Дисертація на здобуття наукового ступеня кандидата економічних наук. Кіровоградський Національний технічний університет . - Кіровоград . - 2016. - 269 с.

8. Овчаренко М.I. Організаційно-економічні засади управління розвитком корпоративної культури промислових підприємств / М.І. Овчаренко // Дисертація на здобуття наукового ступеня кандидата економічних наук. Сумський державний університет . - Суми . - 2014. - 235 с.

9. Максименко А. А. Организационная культура : системнопсихологические описания : Учебное пособие / А. А. Максименко. - Кострома: КГУ, 2003.-168

10. Жерихов Е.С. Корпоративная культура как фактор социальной адаптации личности: Автореф. . дис. канд. филос. наук. М., 2005.

11. Журавлева Е. А. Корпоративная культура как фактор повышения ефективності деятельности предприятия: дис. на соискание ученой степени к.э.н. Специальность 08.00.05. - Москва. - 2010. с. 165

\section{REFERENCES}

1. Arnautova Yu.E. (2008) Srednevekovye istoki sovremennoj korporativnoj kultury [Medieval origins of modern corporate culture] /Menedzhment v Rossii i za rubezhom [in Russian].

2. Pul M., M. Uorner (2002) Pravlenie chelovecheskimi resursami [Human Resource Management] /spb. : Piter, [in Russian].

3. Fey C.F., Denison D.R. (1998) Organizational Culture and Effectiveness: the Case of Foreign Firms of Russia. Working Paper Number 179.

4. Fayol Henri. (1916) Administration Industrielle et Générale

5. Hofstede Geert Culture's Consequencer: International Differences in Work Related Volues (1980). London: Sage Publications

6. Meskon M. Albert M., Xedouri F. (1997) Osnovy menedzhmenta [Fundamentals of Management] / Moskva : Izdatelstvo "Delo", [in Russian].

7. Belyak T.O. (2016) Akty`vizaciya vply`vu korporaty`vnoyi kul tury`na rozvy`tok social`no-trudovy`x vidnosy`n [Activation of the influence of corporate culture on the development of social and labor relations]. Candidate's thesis. Kirovograd [in Ukrainian]

8. Ovcharenko M.I. (2014) Organizacijno-ekonomichni zasady` upravlinnya rozvy`tkom korporaty`vnoyi kul `tury` promy`slovy`x pidpry`yemstv [Organizational and economic principles of management of the development of the corporate culture of industrial enterprises]. Candidate's thesis. Sumy [in Ukrainian].

9. Maksimenko A. A. (2003) Organizacionnaya kultura : sistemnopsixologicheskie opisaniya : uchebnoe posobie [Organizational culture: system-psychological descriptions: Textbook] /Kostroma: kgu, [in Russian].

10. Zherixov E.S. (2005) Korporativnaya kultura kak faktor socialnoj adaptacii lichnosti [Corporate Culture as a Factor of Social Adaptation of the Personality]: avtoref. . dis. kand. filos. nauk. m., [in Russian].

Zhuravleva E. A. (2010) Korporativnaya kultura kak faktor povysheniya efektivnosti deyatelnosti predpriyatiya [Corporate culture as a factor in increasing the efficiency of the enterprise]: dis. na soiskanie uchenoj stepeni k.e.n. specialnost 08.00.05. - Moskva, [in Russian].

Одержано 20.07.2018 p. 